\title{
Thirteen years on the hunt for Buxbaumia viridis in the Czech Republic: still on the tip of the iceberg?
}

\author{
Eva Holá1,2*, Jan Vrba², Renata Linhartová2 , Eva Novozámská3 ${ }^{3}$ Magda Zmrhalová4, Vítězslav Plášek ${ }^{5}$, \\ Jan Kučera ${ }^{1}$ \\ 'Department of Botany, University of South Bohemia, Branišovská 31, 37005 České Budějovice, Czech Republic \\ ${ }^{2}$ Nature Conservation Agency of the Czech Republic, Kaplanova 1931/1, 14800 Prague 11, Czech Republic \\ ${ }^{3}$ Prague Botanic Garden, Nádvorní 134, 17100 Prague 7, Czech Republic \\ ${ }^{4}$ Regional Museum in Šumperk, Hlavní tř. 22, 78731 Šumperk, Czech Republic \\ ${ }^{5}$ Department of Biology and Ecology, University of Ostrava, Chittussiho 10, 71000 0strava, Czech Republic
}

\begin{abstract}
Rare epixylic moss Buxbaumia viridis, which is one of the "Annex II" species of the European "Habitat directive", has been recorded at 124 localities in the Czech Republic in course of the last 13 years. Most of them were discovered in the last five years following a dedicated search at both historical sites of occurrence and new localities with putatively suitable habitat conditions. The recent and historical area of occupancy and extent of occurrence are not obviously different, although most of the recent localities are concentrated in the Western Carpathians and the Hrubý Jeseník Mts. Surprisingly, only 38\% of the localities are located in natural forest habitats, of which herb-rich and acidophilous beech forests were among the most commonly inhabited ones. The rest of occurrences were recorded in non-natural forests (habitats strongly influenced or created by man), particularly the coniferous forest plantations. Sufficient amount of decaying wood of the advanced decay stages, as well as sufficient and constant humidity are crucial prerequisites for the occurrence of $B$. viridis in both types of forests. True epixylic moss Herzogiella seligeri and the liverwort Chiloscyphus profundus were recorded as the most common associated species, while the rest of commonly co-occurring species were facultatively epixylic, ground or ubiquitous bryophytes; other specialized and rare epixylic mosses or liverworts were only rarely recorded. We also designed a potential distribution model for $B$. viridis based on the distribution of habitats most commonly occupied by the studied moss. Despite the simplicity of the model, its close match with the recent distribution in the Western Carpathians, the Hrubý Jeseník Mts. and Šmava Mts. supports its relevance for the real distribution of B. viridis.
\end{abstract}

Keywords: Buxbaumia viridis; Czech Republic; epixylic bryophyte; the "Habitat directive"; threatened bryophyte

\section{Introduction}

Although the Central European landscape is extensively forested, most of these forests are strongly impacted by human activity. In the Czech Republic, the area of forest has been reported to account for about $35 \%$ but only a third of them (about $10 \%$ of the country) are considered to have near-natural composition [1]. Nature-like old-growth forests became extremely rare and heavily fragmented in whole Europe [2]. The degradation and fragmentation of natural forests poses a significant threat to biodiversity, as shown in several comparative studies $[3,4]$. One of the key factors affecting the biodiversity in managed production forests is the complete removal of wood during harvesting $[5,6]$.

*Corresponding author. Email: eva.neurazy@gmail.com

Handling Editor: Zygmunt Kącki
Decaying wood in different stages of decay is a substratum for many invertebrates, fungi, lichens and bryophytes. The threatened nature of epixylic bryophytes has been reflected in the red lists of most European countries [2,7].

A "flagship species" of rare and endangered epixylic mosses is Buxbaumia viridis, which received Europe-wide attention as one of the "Annex II" species of the "Habitat directive" [8]. It is a tiny and inconspicuous moss, which can be traced only in its sporophytic stage due to the extremely reduced gametophyte, and thus makes its recording hard even for an experienced bryologist. Its dioicy, resulting in low fertilization rate together with low establishment and poor competitive abilities of the minute gametophyte have been speculated to be among the main reasons for the rarity of $B$. viridis [9]. In addition, the species is sensitive to desiccation of its substratum and the insufficient air humidity or low precipitation during the summer months restrict spore production and germination [9-11]. 
The occurrence of $B$. viridis is generally restricted to decaying wood, especially in advanced phases of decay [12]. Its detailed ecological requirements have however only been investigated in a few studies $[9,10,13]$, focused mainly on substratum preference. The species is assumed to grow mainly in old-growth (primeval) forests [13].

We have summarized the information about the current occurrences of $B$. viridis in the Czech Republic, which has accumulated over the last thirteen years (2001-2013) and compared the recent and historical distribution pattern. The ecological information noted by the recorders, together with data from habitat mapping were used to develop a model predicting its distribution over the whole area of the country.

\section{Material and methods}

Buxbaumia viridis has been mapped by the Nature Conservation Agency of the Czech Republic since 2001. Positively mapped localities (i.e. localities with $B$. viridis) were visited at least once (see Appendix S1; number of visits is dependent on the availability of sites, the number of surveyor and on the budget for the respective year). The mapping was usually carried out during autumn season, because sporophytes of B. viridis were easily visible. Presence of dead wood, forest type, and forest age were considered as main features for selection of areas. In addition, the vast majority of historical localities [13-15] were included in the survey. In the case of the positive discovery at a locality, neighboring logs (typically within ca. $500 \mathrm{~m}$ ) were particularly thoroughly searched for additional occurrences (microlocalities). At each microlocality, the number of capsules was recorded together with substratum data (the identity of decaying wood where detectable, decay degree) and co-occurring species. The decay degree was measured using a semi-quantitative scale modified from Söderström [16] (Tab. 1). Co-occurring species were defined as those occurring within $15 \mathrm{~cm}$ from the capsules of $B$. viridis; the nomenclature of bryophytes follows the current checklist [17]. Bryophytes were divided into four ecological groups: epiphytes (species commonly found on living trees), ground flora (most often recorded on the ground), true epixylic species (exclusively found on rotting wood) and facultative epixylic species (rotting

Tab. 1 Scale for identification of decay degree [16].

\begin{tabular}{ll}
$\begin{array}{l}\text { Decay } \\
\text { degree }\end{array}$ & Description of decay degree \\
\hline 1 & freshly fallen log, hard, whole, bark intact, branches present \\
2 & log solid, wood hard, more than $50 \%$ of bark present \\
3 & some patches of soft wood, more than $50 \%$ of bark missing \\
4 & wood softening, outline retained, bark missing \\
5 & $\begin{array}{l}\text { log outline slightly deformed } \\
6\end{array}$ \\
7 & $\begin{array}{l}\text { pieces of soft wood, log outline still distinguishable } \\
8\end{array}$ \\
& $\begin{array}{l}\text { log outline indeterminable, humification } 100 \%, \text { no } \\
\text { evidence of hard wood }\end{array}$ \\
\hline
\end{tabular}

wood is only sub-optimal substratum). The assignation of the species to these groups followed other studies $[18,19]$ and own experience.

Localities were defined as one or more logs of B. viridis within the radius of $500 \mathrm{~m}$. Except for a few exceptions (Appendix S1), only one habitat type occurred at one locality. For each locality, mean altitude, and for each microlocality distance from the nearest watercourse were assessed from topographic maps. The distance from watercourse was classified into 4 categories: (i) up to $10 \mathrm{~m}$; (ii) $11-100 \mathrm{~m}$; (iii) 101-500 m; (iv) $>500 \mathrm{~m}$, i.e. no watercourse.

Another type of data assigned to localities was the habitat information. These data were extracted from the geographic information system (GIS) layer of the habitat mapping of the Czech Republic [20]. The habitats were classified according to habitat catalogue [21]. This classification utilizes primarily the formation-vegetation (physiognomic) approach and, secondarily, the floristic approach. The habitats of supposedly higher importance for nature conservation are termed natural habitats. In contrast, the non-natural habitats are those of presumably lower importance for biodiversity or nature conservation and are strongly influenced or created by humans [21]. In addition, syntopic combinations (mosaics) of natural and non-natural habitats can occur. If one of the habitats from the mosaic was non-natural, then the entire mosaic was considered as a non-natural habitat. In the areas of supposedly low frequency of natural habitats, only the natural habitats were recorded and mapped (so-called contextual mapping; [22]), whereas the non-natural habitats were not mapped and were merged in the resulting GIS layer in a single category, labelled " -1 ".

For the analysis of distribution, we defined the area of occupancy as the number of the occupied grid squares of the Central European floristic grid [23], with the squares $5 \times 3$ geographical minutes. Extent of occurrence is defined as the area contained within the shortest continuous imaginary boundary, which can be drawn to encompass all the known, inferred or projected sites of present occurrence of a species [24]. The distance of the farthest points was set to be $40 \mathrm{~km}$ [25]. The area of the occupied grid squares and extent of occurrence were calculated using ArcGis ver. 9 [26].

We combined the GIS layer of habitat mapping [20] and the Corine land cover layer [27] with our results of habitat association frequency and altitudinal distribution of $B$. viridis for the construction of the map of its potential distribution. The Corine land cover refers to the European programme establishing a computerized inventory on land cover of the 27 European Union member countries and other European countries, at an original scale of 1:100 000, using 44 classes with five main categories - artificial surfaces, agricultural areas, forest and other semi-natural areas, wetlands, and water bodies. Forests are subdivided into three categories broad-leaved, coniferous, and mixed forests. Most frequently occupied habitats (i.e., habitats of interest, habitats in which the occurrence of $B$. viridis was more frequent than five times, see "Results") and their mosaics (only mosaics wherein the representation of habitats of interest was higher than 50\%) within altitudes $300-1100 \mathrm{~m}$ a.s.l. were included in the model. The potential distribution map was constructed as the relative proportion of habitat area (only habitats of interest) 
per each square. For the non-natural habitats merged in the category " -1 " (one of the habitats of interest) in the layer of the habitat mapping, the information from the Corine land cover layer was used to select coniferous and broad leaved-coniferous forests. Only these two types of " -1 " habitats were used in the modeling of potential distribution of $B$. viridis. All other " -1 " habitats were regarded as completely uninhabitable for $B$. viridis.

The general linear model, calculated by $\mathrm{R}$ version 2.12 [28], was used to test the influence of the altitude, habitat type (natural vs. non-natural), habitat unit, degree of decay, and distance from watercourse on the sporophyte production, measured as the mean number of capsules per each locality. The mean number of sporophytes per each locality was log-transformed prior to analysis to improve normality.

\section{Results}

\section{Historical and recent distribution}

Buxbaumia viridis has to date been recorded on 167 localities in the Czech Republic (Fig. 1, Tab. 2, Appendix S1). One hundred twenty four localities (and 192 microlocalities) were recorded in the recent 13 years (2001-2013), of which 89 localities were newly found occurrences. Of the 78 historical localities (recorded before 2001 [13-15]), 35 were checked with positive results, while at 21 localities $B$. viridis was not re-found and 22 historical records were not verified due to insufficient capacities, inaccurate localization etc. Since 2001, 242 sites were explored in total (i.e., both revision of historical localities and survey of newly selected ones), B. viridis was not found at 118 of them (Fig. 2).

Although the number of recent localities is higher than the number of historical localities, the area and extent of occurrence of historical localities reached higher values

\section{Recent and historical localities, $N=167$}

(Tab. 2). Altitudinal distribution of the localities spanned 250-1200 m, of which most were recorded at the altitudes between $600-900 \mathrm{~m}$ a.s.l. (Fig. 3). 42\% of all microlocalities $(N=192)$ were situated within $10 \mathrm{~m}$ from a watercourse, $32 \%$ microlocalities within 11-100 $\mathrm{m}$ from a watercourse, $23 \%$ microlocalities within 101-500 m from a watercourse and only 4 microlocalities were farther than $500 \mathrm{~m}$ from watercourse (Fig. 4).

\section{Habitat requirements and association, co-occurring species}

The recorded substratum of $B$. viridis was primarily the decaying wood of conifers in late decay phases (degree 5, 6, 7 or 8 ; Fig. 5). Of the 148 cases (microlocalities), when the substratum could be determined, $88 \%$ were conifers (mainly Picea abies and Abies alba) and $12 \%$ were broad leaved trees, mainly beech (Fagus sylvatica; 8\%), 1-2 microlocalities were

Tab. 2 The area of occupancy (AOO) and the extent of occurrence (EOO) for recent and historical localities were summarized.

\begin{tabular}{lccc} 
Recent localitis & $\boldsymbol{N}$ & AOO & EOO $\left(\mathbf{k m}^{2}\right)$ \\
\hline 124 & 74 & 4445 \\
Historical localitis & $N$ & AOO & EOO $\left(\mathbf{k m}^{2}\right)$ \\
\hline & 78 & 66 & 4359
\end{tabular}

The grid squares are defined by the project "Kartierung der Flora Mitteleuropas" (KFME), with the squares of 5 ' longitude and 3 ' latitude.

Recent localities (2001-2013), N = 124


historical localities (recorded before 2001) - checked with negative results $\square$ historical localities (recorded before 2001) - no check
$\square$ newly found localities (2001-2013)
- historical localities (recorded before 2001) - checked with positive results

Fig. 1 The number of historical and recent localities. 

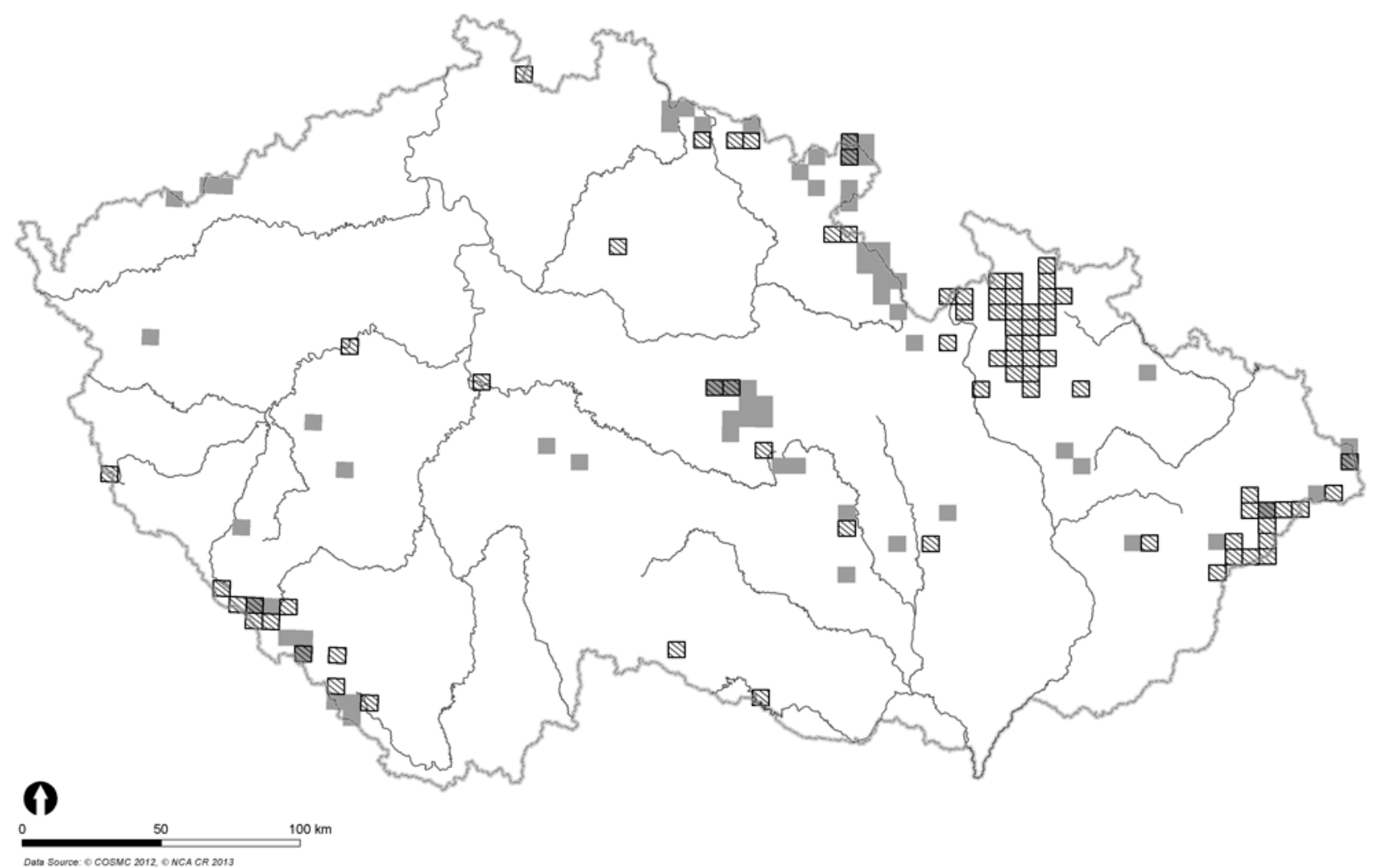

Fig. 2 Map of explored area. Hatched squares show positively explored area; grey squares are negatively explored area. The grid squares are defined by the project "Kartierung der Flora Mitteleuropas" (KFME), with the squares of 5' longitude and 3' latitude.

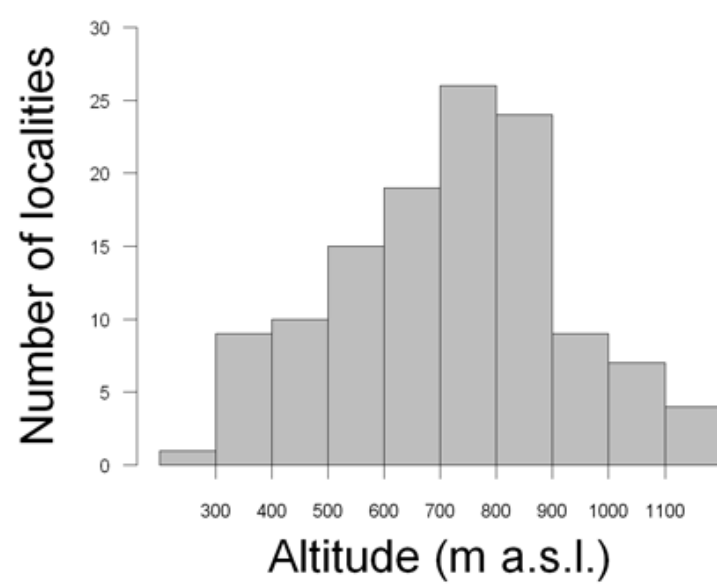

Fig. 3 Altitudinal distribution for recent localities of B. viridis from the Czech Republic; $N=124$.

recorded for alder (Alnus glutinosa), ash (Fraxinus excelsior) and birch (Betula pendula).

The co-occurring species and their frequency at recent microlocalities are summarized in Tab. 3. Altogether, 68 species were recorded (24 liverworts and 44 mosses), of which the most common (growing at more than $40 \%$ of microlocalities) were liverwort Chiloscyphus profundus and mosses Herzogiella seligeri, Rhizomnium punctatum, Dicranum scoparium and Tetraphis pellucida. Forest ground

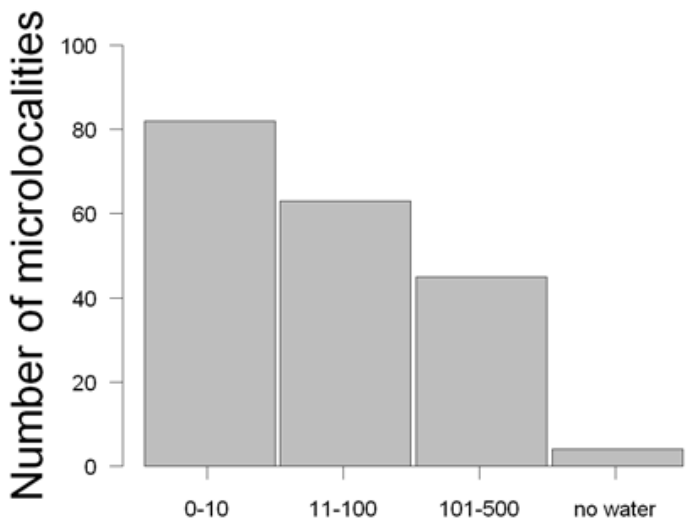

Distance from watercourse $(\mathrm{m})$

Fig. 4 Distance of $B$. viridis microlocalities from a watercourse; $N=192$.

species dominated among co-occurring species (40 species), whereas only 9 species were classified as true epixylic species and 17 as facultative epixylic species, 3 as the epiphytes. Nevertheless, the most common accompanying species (see above) were true or facultative epixylic species.

The mean number of sporophytes per one microlocality varied from 1 to 108 capsules (mean $=8$, median $=3$ ), most microlocalities (80\%) and localities (70\%) had only up to 10 sporophytes. However, number of sporophytes 
Tab. 3 Co-occurring species at microlocalities of B. viridis.

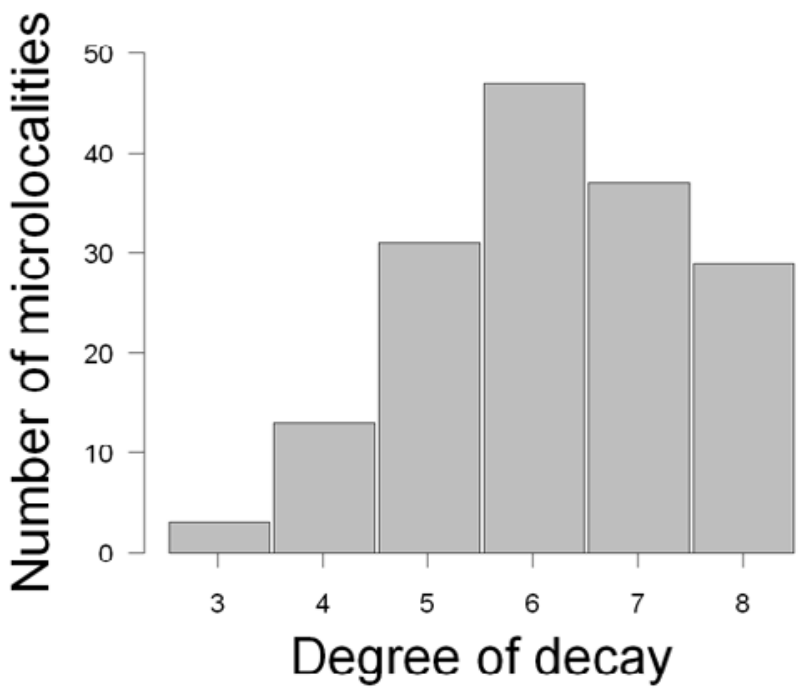

Fig. 5 Frequency of different decay stages of logs (microlocalities) with presence of $B$. viridis; $N=160$ (modified from Söderström [16] - (3) some patches of soft wood, more than $50 \%$ of bark missing; (4) wood softening, outline retained, bark missing; (5) log outline slightly deformed; (6) pieces of soft wood, log outline still distinguishable; (7) only log core remains; (8) log outline indeterminable, humification $100 \%$, no evidence of hard wood).

on microlocalities varied among years, e.g. at the locality Halenkov (195 sporophytes in 2001, 6 sporophytes in 2011), Senice - Val. Kyčera (7 sporophytes in 2002, 64 sporophytes in 2011), Vrchovištní pot. (94 sporophytes in 2001, 14 sporophytes in 2009). The numbers for all localities are listed in the Appendix S1. The average number of sporophytes per locality showed no relation to altitude $(F=2.3924, P$ $=0.1254)$, habitat type $(F=0.0432, P=0.8357)$, habitat unit $(F=1.6006, P=0.1463)$, decay degree $(F=3.4437$, $P=0.0667)$, or watercourse $(F=2.2432, P=0.1377)$. It seems that variation among years is an important predictor of persistence of $B$. viridis on locality. However, our data do not allow us this type of analysis because we have not accumulated sufficient amount of repeated observations from each locality.

Only $38 \%$ of recent localities were situated in 6 habitats units and 17 subunits, which are classified as natural according to habitat mapping GIS layer (Tab. 4). The remaining localities were recorded in 3 units and 8 subunits of habitats classified as non-natural. The most common natural habitats were beech forests, particularly herb-rich and acidophilus beech forests, the most common non-natural habitats were non-specified habitats of contextual mapping and habitats strongly influenced or created by man, particularly the forest plantations of coniferous trees.

\section{Potential distribution map}

The potential distribution model is shown in Fig. 6. The model and recent distribution show a close match mainly in the Western Carpathians and the Hrubý Jeseník Mts., where there are frequent records of $B$. viridis as well as the

\begin{tabular}{|c|c|c|}
\hline Species & $\begin{array}{l}\% \text { of co-occurring } \\
\text { species }(N=169)\end{array}$ & $\begin{array}{c}\text { Ecological } \\
\text { category }\end{array}$ \\
\hline \multicolumn{3}{|l|}{ Liverworts } \\
\hline Chiloscyphus profundus & 56 & $\mathrm{TX}$ \\
\hline Cephalozia bicuspidata & 31 & FX \\
\hline Lepidozia reptans & 27 & $\mathrm{TX}$ \\
\hline Blepharostoma trichophyllum & 16 & FX \\
\hline Plagiochila porelloides & 11 & G \\
\hline Scapania nemorea & 8 & FX \\
\hline \multicolumn{3}{|l|}{ Mosses } \\
\hline Herzogiella seligeri & 70 & $\mathrm{TX}$ \\
\hline Rhizomnium punctatum & 50 & FX \\
\hline Dicranum scoparium & 45 & FX \\
\hline Tetraphis pellucida & 40 & $\mathrm{TX}$ \\
\hline Dicranum montanum & 28 & $\mathrm{E}$ \\
\hline Hypnum cupressiforme & 21 & FX \\
\hline Sanionia uncinata & 17 & FX \\
\hline Plagiothecium curvifolium & 12 & G \\
\hline Dicranella heretomalla & 12 & G \\
\hline Polytrichum formosum & 12 & G \\
\hline Pohlia nutans & 11 & G \\
\hline Atrichum undulatum & 9 & G \\
\hline Dicranodontium denudatum & 7 & $\mathrm{TX}$ \\
\hline Plagiomnium affine & 6 & G \\
\hline Plagiothecium laetum & 6 & G \\
\hline Sciuro-hypnum reflexum & 6 & G \\
\hline
\end{tabular}

Bryophytes with low frequency (less than 5\%). Liverworts: Bazzania trilobata (ecological category: G), Calypogeia azurea (G), C. integristipula (G), Crossocalyx hellerianus (TX), Chiloscyphus coadunatus (G), Ch. cuspidatus (G), Diplophyllum obtusifolium (G), Liochlaena lanceolata (FX), Lophozia ascendens (TX), Lophozia ventricosa (FX), Marchantia polymorpha (G), Nowellia curvifolia (TX), Orthocaulis attenuatus (FX), Ptilidium pulcherrimum (E), Riccardia latifrons (TX), Riccardia palmata (TX), Schistochilopsis incisa (FX), Tritomaria exsectiformis (FX). Mosses: Aulacomnium androgynum (FX), Brachythecium rivulare $(\mathrm{G})$, B. rutabulum $(\mathrm{G})$, B. salebrosum (FX), B. velutinum (FX), Bryum moravicum (E), Buxbaumia aphylla (G), Cirriphyllum piliferum (G), Dicranella subulata (G), Dichodontium pellucidum (G), Eurhynchium angustirete (G), Hylocomium splendens (G), Mnium hornum (G), M. spinosum $(\mathrm{G})$, Plagiomnium cuspidatum (FX), P. undulatum $(\mathrm{G})$, Plagiothecium curvifolium (G), P. nemorale (G), P. succulentum (G), Pleurozium schreberi (G), Pogonatum urnigerum (G), Polytrichum juniperinum (G), P. longisetum (G), Rhynchostegium riparioides $(\mathrm{G})$, Rhytidiadelphus loreus (G), Sciuro-hypnum curtum (G), Sphagnum girgensohnii (G), Thuidium tamariscinum $(\mathrm{G})$. Ecological categories: E - epiphyte, FX - facultative epixylic species, G - ground species, TX - true epixylic species and.

high modeled probability of its occurrence (cf. Fig. 2 and Fig. 6). The high probability of occurrence according to the model is also reflected in at least several recent records of B. viridis in Moravian Karst, Giant Mts. and Šumava Mts. On the other hand, the relatively high modeled probability of occurrence contrasts with only two positive recent records 
Tab. 4 Representation of habitats on recent localities of Buxbaumia viridis $(N=121)$.

\begin{tabular}{|c|c|c|c|c|c|}
\hline Forest habitat & $N$ & Habitat unit & $N$ & Habitat subunit & $N$ \\
\hline \multirow[t]{17}{*}{ Natural } & 46 & Alluvial forests (L2) & 2 & Ash-alder alluvial forests (L2.2) & 2 \\
\hline & & Oak-hornbeam forests (L3) & 2 & Hercynian oak-hornbeam forests (L3.1) & 2 \\
\hline & & Ravine forests (L4) & 3 & Ravine forests (L4) & 3 \\
\hline & & Beech forests (L5) & 24 & Herb-rich beech forests (L5.1) & 12 \\
\hline & & & & Montane sycamore-beech forests (L5.2) & 3 \\
\hline & & & & Acidophilous beech forests (L5.4) & 9 \\
\hline & & Spruce forests (L9) & 4 & Montane Calamagrostis spruce forests (L9.1) & 2 \\
\hline & & & & Bog and waterlogged spruce forests (L9.2) & 1 \\
\hline & & & & Montane Athyrium spruce forests (L9.3) & 1 \\
\hline & & Mosaic & 11 & Ash-alder alluvial forests (L2.2) + ravine forests (L4) & 1 \\
\hline & & & & $\begin{array}{l}\text { Ravine forests (L4) + chasmophytic vegetation of siliceous cliffs and boulder } \\
\text { screes (S1.2) }\end{array}$ & 2 \\
\hline & & & & $\begin{array}{l}\text { Ravine forests (L4) + chasmophytic vegetation of calcareous cliffs and } \\
\text { boulder screes (S1.1) }\end{array}$ & 1 \\
\hline & & & & $\begin{array}{l}\text { Herb-rich beech forests (L5.1) + chasmophytic vegetation of siliceous cliffs } \\
\text { and boulder screes (S1.2) }\end{array}$ & 2 \\
\hline & & & & Herb-rich beech forests (L5.1) + ravine forests (L4) & 2 \\
\hline & & & & $\begin{array}{l}\text { Herb-rich beech forests (L5.1) + chasmophytic vegetation of calcareous cliffs } \\
\text { and boulder screes (S1.1) }\end{array}$ & 1 \\
\hline & & & & Acidophilous beech forests (L5.4) + herb-rich beech forests (L5.1) & 1 \\
\hline & & & & Herb-rich beech forests (L5.1) + forest springs without tufa formation (R1.4) & 1 \\
\hline \multirow[t]{8}{*}{ Non-natural } & 75 & Contextual mapping $(-1)$ & 41 & Contextual mapping $(-1)$ & 41 \\
\hline & & $\begin{array}{l}\text { Habitats strongly influenced } \\
\text { or created by man }(\mathrm{X})\end{array}$ & 27 & Anthropogenic areas with sparse vegetation (X6) & 1 \\
\hline & & & & Forest plantations of coniferous trees (X9A) & 22 \\
\hline & & & & Forest clearings (X10) & 4 \\
\hline & & Mosaic & 7 & Ash-alder alluvial forests (L2.2) + forest plantations of coniferous trees (X9A) & 3 \\
\hline & & & & Forest plantations of coniferous trees (X9A) + herb-rich beech forests (L5.1) & 2 \\
\hline & & & & Forest plantations of coniferous trees $(\mathrm{X} 9 \mathrm{~A})+$ forest clearings $(\mathrm{X} 10)$ & 1 \\
\hline & & & & Forest clearings $(\mathrm{X} 10)+$ forest springs without tufa formation (R1.4) & 1 \\
\hline
\end{tabular}

Mainly microlocalities of one locality belonged to same habitat type. Only a few microlocalities of three localities differed in habitat type (for more details see Appendix S1), this localities were not included. Most frequented habitat subunits (habitats of interest) are highlighted.

in the Orlické hory Mts., although we paid an adequate effort to the recent focused search for the species (cf. Fig. 2 and Fig. 6). The military area Brdy remains among regions with the high-modeled probability of occurrence and inadequate recent exploration.

\section{Discussion}

\section{Historical and recent distribution}

The considerable amount of recent localities, especially in the Hrubý Jeseník in the last five years, cannot be interpreted in terms of the recent spread of the species. Rather, we could see the increasing intensity of the exploration, together perhaps with the increasingly better search strategy and knowledge of ecology, resulting in the more focused search of the surveyors. In addition, Buxbaumia viridis was re-found at nearly a half of the historical localities (44\%), which convincingly shows that the species may persist at the localities for a long time, provided that sufficient amount of suitable deadwood is retained, as most of the historical localities date back to or precede the 1950s. Even though, B. viridis may be still under-recorded, as the rate of its potentially suitable habitats, visible only in sporophyte stage to the number of surveyors, is still far too high. On the other hand, the survey density and success rate in finding is probably highest in the Czech Republic in comparison with neighboring countries. About 95 recent localities have been found in significantly larger Germany [29] and 85 were reported from Austria [30], and only 15 localities were recorded in Slovakia [31]. In neighboring Poland, the current state of the population is less known. The species was reported from tens of localities over a wide geographic range, discovered mainly in the 19th century [32]. Most occurrences were reported from the Western Carpathians, as well as in the Sudety Mts. and the Sudety foothills [32]. Nevertheless, even in Poland, the trend of recent discoveries of new localities has been observed [33-36]. 


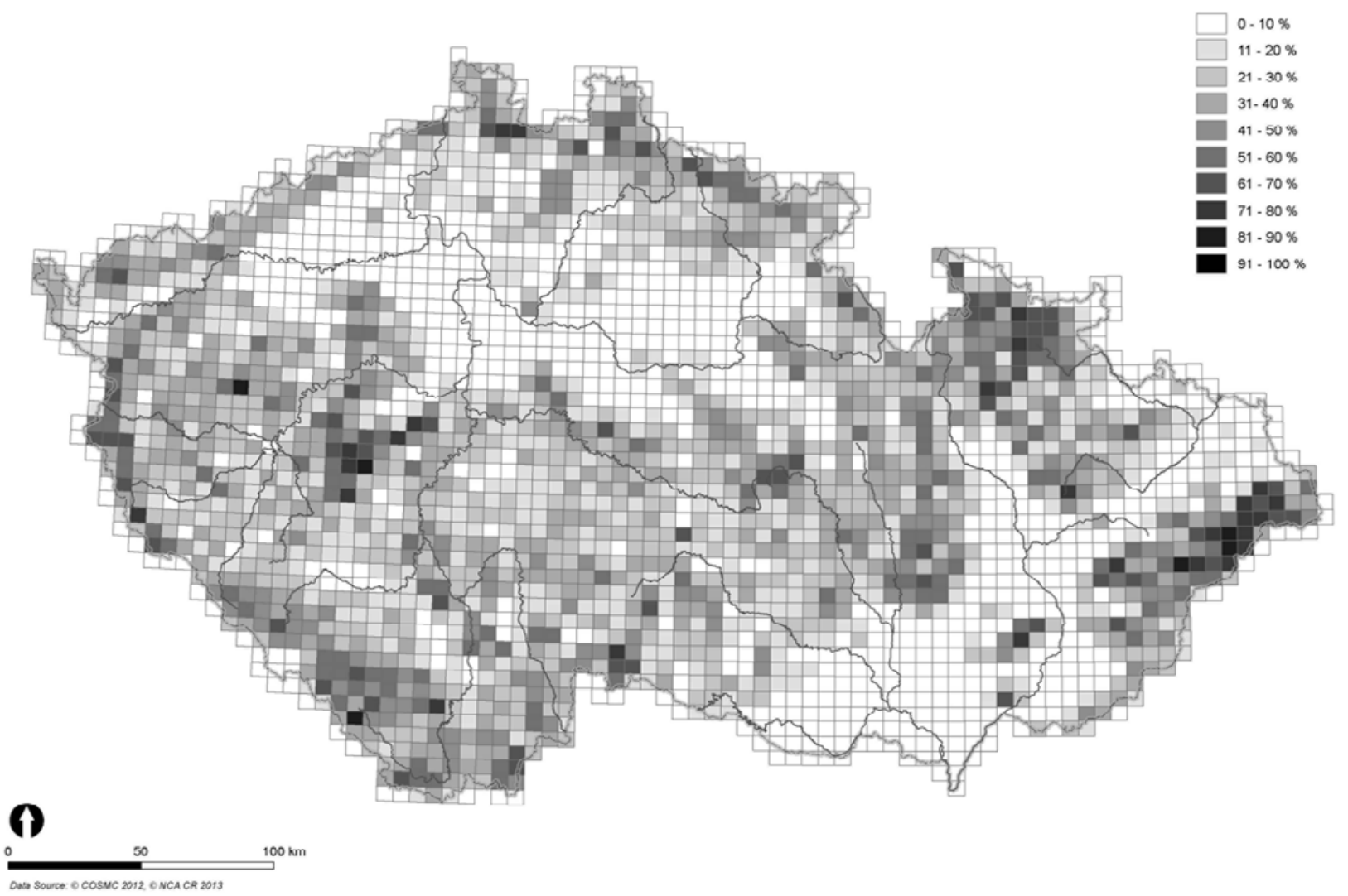

Fig. 6 Potential distribution map of B. viridis, the relative proportion of habitat area (only habitats of interest) per each square are given. The grid squares are defined by the project "Kartierung der Flora Mitteleuropas" (KFME), with the squares of 5 ' longitude and 3 ' latitude.

Most of the recent localities are situated in the Western Carpathians and the Hrubý Jeseník Mts., while the historical localities were distributed more evenly in the Czech Republic. However, the recent and historical area of occupancy and extent of occurrence are not obviously different. The highest density of recent occurrences in the mountains of the northeastern part of Czech Republic agrees well with our model of potential distribution (Fig. 6). The reasons for this pattern might include the highest proportion of forests [37], ideal span of altitude, and generally more humid conditions, resulting from high precipitation averages [38] and favorable geomorphology. At the same time, the Western Carpathians and the Hrubý Jeseník Mts. are the best-explored areas for the species in the recent period (Fig. 2), in contrast to the historical state. Other well-researched mountain regions of Czech Republic (Orlické hory Mts., Giant Mts.) demonstrably support a much smaller number of recent localities (Fig. 2), which implies that the Western Carpathians and the Hrubý Jeseník Mts. indeed represent the core area for the occurrence of B. viridis in the Czech Republic. In addition, many new records in the Šumava Mts. during the two last years of focused survey suggest that the real situation here might be closer to that of Western Carpathians and the Hrubý Jeseník Mts. than previously thought. However, additional survey in the Šumava Mts. is needed to confirm this trend.

\section{Habitat requirements and co-occurring species}

The most important abiotic factor, which affects the occurrence of $B$. viridis is probably the humidity. The insufficient moisture was speculated to hamper the sporophyte production by the inhibition of gametangia and fertilization, or death of the protonema [9]. B. viridis also prefers the wood in advanced phases of decay, with high and fairly constant water content. Indeed, the majority of sites were located within 100 $\mathrm{m}$ from a stream. The exact pattern of the yearly course of air humidity at the sites, which is probably crucial for the successful establishment of gametophytes and development of sporophytes, is nevertheless much more difficult to trace. Our data unfortunately do not allow any scholarly analysis in this way, particularly because the GIS layer used for the retrieval of watercourses might not have included smaller streams, which nevertheless provide the sufficient source of humidity for the development of Buxbaumia sporophytes.

Epixylic bryophytes do not seem to be restricted to specific wood species $[3,9]$. This was confirmed for B. viridis, although Spruce logs were the most frequently occupied substratum. This may be due to the better holding capacity of brown-rot fungi that grow in conifer wood $[9,18]$.

$B$. viridis tends to occur with rather common moss species. It prefers mosses to liverworts, and only two of the most frequently recorded mosses (Herzogiella seligeri, Tetraphis pellucida) are rather specifically associated with dead wood (true epixylic mosses) in the Czech Republic. True epixylic liverworts are generally good indicators of the high air-humidity, being moisture-demanding or intolerable of prolonged drought periods. However, B. viridis rarely if ever grows associated with such liverworts (Crossocalyx hellerianus, Lophozia ascendens, Nowellia curvifolia), which seems 
to be contradictory to the general demand on air humidity discussed above. Protonematal growth of B. viridis is very slow (0.5-3 mm after 70 days in cultivation) and does not seem to expand rapidly to the empty space [10]. Therefore, $B$. viridis is probably not successful in competitive interaction with bryophytes during the juvenile stage of the life cycle. The pleurocarpous mosses, which are commonly associated with the sporophytes of B. viridis (Herzogiella seligeri, Hypnum cupressiforme, Sanionia uncinata) may provide shadier and damper shelter for germination and protonematal growth of $B$. viridis than tiny liverworts.

\section{Habitat association and potential distribution}

$B$. viridis is generally considered to be an indicator species of old-growth (primeval) forests (e.g. [13,39]). Nevertheless, only $38 \%$ of the Czech localities are situated in natural forest habitats, while the rest is situated in managed forests, most

\section{Acknowledgments}

We thank Jan Košnar (University of Hradec Králové), Veronika Oušková, Iva Hönigová (Nature Conservation Agency) for heplful discussion of the manuscript and to all bryologists mainly Štěpán Koval, who participated in the monitoring. We acknowledge the financial support of the Nature Conservation Agency of the Czech Republic, Grant Agency of the University of South Bohemia in České Budějovice 138/2010/P, the project Institute of Environmental Technologies, reg. No. CZ.1.05/2.1.00/03.0100, supported by the "Research and development for innovations" operational program and project of the "National feasibility programme" of the Czech Republic LO1208.

\section{Authors' contributions}

The following declarations about authors' contributions to the research have been made: responsible for coordination of monitoring Buxbaumia viridis (since 2008), field work, data and GIS analysis, paper writing and manuscript preparation: EH; GIS analysis: JV; field work, manuscript preparation: EN, MZ, VP; coordination of monitoring Buxbaumia viridis (2000-2007), field work: RL; field work, paper writing and manuscript preparation: JK.

\section{Supplementary material}

The following supplementary material for this article is available online at http://pbsociety.org.pl/journals/index.php/asbp/rt/suppFiles/ asbp.2014.015/0:

1. Appendix S1: historical and recent records of Buxbaumia viridis in the Czech Republic.

\section{References}

1. Miko L, Hošek M, editors. State of nature and landscape in the Czech Republic. Prague: AOPK ČR; 2009.

2. Hallingbäck T, Hodgetts N, editors. Mosses, liverworts, and hornworts: status survey and conservation action plan for bryophytes. Gland: IUCN/SSC Bryophyte Specialist Group; 2000.

3. Andersson LI, Hytteborn H. Bryophytes and decaying wood a comparison between managed and natural forest. Ecography. 1991;14(2):121-130. http://dx.doi.org/10.1111/j.1600-0587.1991. tb00642.x

4. Vellak K, Paal J. Diversity of bryophyte vegetation in some forest types in Estonia: a comparison of old unmanaged and managed forests. Biodivers Conserv. 1999;8(12):1595-1620. http://dx.doi. org/10.1023/A:1008927501623

5. Riffell S, Verschuyl J, Miller D, Wigley TB. Biofuel harvests, coarse woody debris, and biodiversity - a meta-analysis. For Ecol Manage. 2011;261(4):878-887. http://dx.doi.org/10.1016/j.foreco.2010.12.021

6. Madžule L, Brūmelis G, Tjarve D. Structures determining bryophyte species richness in a managed forest landscape in boreo-nemoral Europe. Biodivers Conserv. 2012;21(2):437-450. http://dx.doi. org/10.1007/s10531-011-0192-Z typically in spruce plantations. It seems that the crucial factor is not habitat association (type of forest) but probably suitable humidity, typically near a watercourse with a sufficient amount of decayed wood. These conditions seem to be crucial for the occurrence of $B$. viridis. However, it is exactly these factors, which are difficult to retrieve, analyze and include to the distribution model. The microclimatic humidity is influenced by topography and substratum characteristics of the logs. The amount of dead wood is not specified in any of the existing databases (cf. habitat mapping [20] and Czech national phytosociological database - ČNFD [40]). Although only the frequency of the most commonly occupied habitat (which is definitely also linked to certain extent to these parameters) was included to the model, its match with the recent distribution shows that the model may be used as a basis for focused search for the new localities of $B$. viridis.

7. Söderström L. Conservation biology of bryophytes. Lindbergia. 2006;3(1-2):24-32.

8. CECC. Directive 92/43/EEC of 21 May 1992 on the conservation of natural habitats and of wild fauna and flora [Internet]. 1992 [cited 2013 Nov 25]; Available from: http://www.nature.cz/publik_syst2/ files08/habitats\%20directive_official\%20text.pdf

9. Wiklund $\mathrm{K}$. Phosphorus concentration and $\mathrm{pH}$ in decaying wood affect establishment of the red-listed moss Buxbaumia viridis. Can J Bot. 2003;81(6):541-549. http://dx.doi.org/10.1139/b03-048

10. Wiklund K. Substratum preference, spore output and temporal variation in sporophyte production of the epixylic moss $B u x$ baumia viridis. J Bryol. 2002;24(3):187-195. http://dx.doi. org $/ 10.1179 / 037366802125001358$

11. Wiklund K, Rydin H. Ecophysiological constraints on spore establishment in bryophytes. Func Ecol. 2004;18(6):907-913. http://dx.doi. org/10.1111/j.0269-8463.2004.00906.x

12. Dierssen K. Distribution, ecological amplitude and phytosociological characterization of European bryophytes. Berlin: Cramer in der Gebrüder Borntraeger Verlagsbuchhandlung; 2001. (Bryophytorum bibliotheca; vol 56).

13. Plášek V. The moss Buxbaumia viridis (Bryopsida, Buxbaumiaceae) in the Czech part of the Western Carpathians - distribution and ecology. In: Stebel A, Ochyra R, editors. Bryological studies in the Western Carpathians. Poznań: Sorus; 2004. p. 37-44.

14. Vondráček M. Prodromus der Moose des Böhmerwaldes (Bryopsida) I. (Sphagnaceae-Bryaceae). Plzeň: Západočeské muzeum; 1990. (Folia musei rerum naturalium Bohemiae occidentalis: botanica; vol 31).

15. Soldán Z. Buxbaumia viridis - a candidate of red lists of bryophytes. Bryonora. 1992;9:40-44.

16. Söderström L. Sequence of bryophytes and lichens in relation to substrate variables of decaying coniferous wood in Northern Sweden. Nord J Bot. 1988;8(1):89-97. http://dx.doi.org/10.1111/j.1756-1051.1988. tb01709.x

17. Kučera J, Váňa J, Hradílek Z. Bryophyte flora of the Czech Republic: updated checklist and red list and a brief analysis. Preslia. 2012;84:813-850.

18. Ódór P, van Hees AFM. Preferences of dead wood inhabiting bryophytes for decay stage, log size and habitat types in Hungarian beech forests. J Bryol. 2004;26(2):79-95. http://dx.doi. org/10.1179/037366804225021038

19. Jansová I, Soldán Z. The habitat factors that affect the composition of bryophyte and lichen communities on fallen logs. Preslia. 2006;78(1):67-86.

20. AOPK ČR. Habitat mapping layer - electronic georeferenced database. Prague: AOPK ČR; 2012. 
21. Chytrý M, Kučera T, Kočí M, Grulach V, Luetyk P, editors. Katalog biotopů České republiky. Prague: AOPK ČR; 2010.

22. Lustyk P, Guth J. Methodology of habitat mapping in the Czech Republic. Prague: AOPK ČR; 2012.

23. Ellenberg H, Haeupler H, Hamann U. Arbeitsanleitung für die Kartierung der Flora Mitteleuropas (Ausgabe für die Bundesrepublik Deutschland). Mitt Flor Soz Arbeitsgem Niedersachs. 1968;13:284-296.

24. IUCN. IUCN red list categories and criteria. Version 3.1. Gland: IUCN Species Survival Commission; 2001.

25. Evans D, Arvela M. Assessment and reporting under Article 17 of the habitats directive. Explanatory notes \& guidelines for the period 2007-2012 [Internet]. 2011 [cited 2013 Nov 25]; Available from: http:// bd.eionet.europa.eu/activities/Reporting/Article_17/reference_portal

26. ArcGIS 9. Using ArcGIS Desktop. Redlands, CA: ESRI; 2006.

27. European Environment Agency. Corine land cover 2000 (CLC2000) seamless vector database [Internet]. 2000 [cited 2013 Nov 25]; Available from: http://www.eea.europa.eu/data-and-maps/data/ corine-land-cover-2000-clc2000-seamless-vector-database

28. R Development Core Team. R: a language and environment for statistical computing. Vienna: R Foundation for Statistical Computing; 2010.

29. Moose-Deutschland. Internetplattform der Zentralstelle Deutschland, Dienstleistungszentrum für die Darstellung biologischer Daten im Internet [Internet]. 2012 [cited 2013 Nov 25]; Available from: http:// www.moose-deutschland.de

30. Eionet. Article 17 - reporting under habitats directive [Internet]. 2009 [cited 2013 Nov 25]; Available from: http://forum.eionet.europa. eu/x_habitat-art17report/library/datasheets/species/plants/plants/ buxbaumia_viridispdf

31. Šubová V, Ambróz J, editors. The atlas of species of European interest of Natura 2000 sites in Slovakia. Český Těšín: FINIDS; 2011.
32. Pawlaczyk P, Kepel A, Jaros R, Dzięciołowski R, Wylegała P, Szubert A, et al. Natura 2000 shadow list in Poland [Internet]. Warsaw: WWF; 2004 [cited 2014 Mar 25]. Available from: http://www.natura2000.hr/ UtilPages/GetDBDocument.aspx?id=133

33. Hajek B. Rozmieszczenie, wymagania środowiskowe oraz fenologia rzadkiego mchu Buxbaumia viridis (Moug. ex Lam. \& DC.) Brid. ex Moug. \& Nestl. w Trójmiejskim Parku Krajobrazowym. Acta Bot Cassub. 2010;7-9:161-175.

34. Cykowska B, Vončina G. Recent occurrence of moss Buxbaumia viridis (Bryophyta, Buxbaumiaceae) in the Kłodzko region (Central and Eastern Sudetes, SW Poland). Čas Slez Zemského Muzea A. 2011;60(1):85-89. http://dx.doi.org/10.2478/v10210-011-0010-y

35. Kozik J, Voncina G. Odkrycie bezlistu okrywowego Buxbaumia viridis (Bryophyta, Buxbaumiaceae) w Beskidzie Niskim (Karpaty Zachodnie). Rocz Bieszczadzkie. 2012;20:378-383.

36. Paciorek T. New locality of moss Buxbaumia viridis (Moug. ex Lam. \& DC.) Brid. ex Moug. \& Nestl. in relation to its distribution in the Beskid Sądecki range (Western Carpathians, Poland). Čas Slez Zemského Muzea A. 2013;61(3):285-288. http://dx.doi.org/10.2478/ v10210-012-0030-2

37. Šafář J. Olomoucko. In: Mackovčin P, Sedláček M, editors. Chráněná území ČR, svazek VI. Prague: AOPK ČR; 2003. p. 290-309.

38. Tolasz R, Míková T, Valeriánová A, Voženílek V, editors. Atlas podnebí Česka. Prague: ČHMÚ, UPOL; 2007.

39. Hallingbäck T, Lönnell N, Weibull H, Hedenäs L, von Knorring P. Nationalyckeln till Sveriges flora och fauna. Bladmossor: Sköldmossor. Bryophyta: Buxbaumia-Lecobryum. Uppsala: ArtDatabanken, SLU; 2006.

40. Chytrý M, Rafajová M. Czech national phytosociological database: basic statistics of the available vegetation-plot data. Preslia. 2003;75:1-15. 